\title{
PERKEMBANGAN KOGNITIF, FISIK, DAN EMOSI SOSIAL PADA MASA PRENATAL
}

\author{
Nurul Maziyatul $\mathbf{H}$ \\ UIN Sunan Kalijaga \\ Email:maziyazio66@gmail.com \\ Dewi Fahmi A \\ UIN Sunan Kalijaga \\ Email:dewifahmi8@gmail.com \\ Avita Febri $\mathbf{H}$ \\ UIN Sunan Kalijaga \\ Email: avitafebri@gmail.com
}

\begin{abstract}
Until now, there are some people who think that a child's development begins when he is born. In fact, progress can be observed during the ovulation stage. From here on, the development of the prospective baby can be observed and studied. Education in the womb is very important for children because at that time children experience early development and growth. While in the womb, the mother is the most important person in shaping the child's intelligence through the education provided. The purpose of this study is to provide some knowledge about the development of children before birth or prenatal. This study uses the Library Research method by examining several data sources from books related to prenatal development. The conclusion of this study is that the development of the prenatal period has a very important effect on children's development. There are several things that must be considered so that children experience perfect development, so that cognitive, physical, and social emotions can develop optimally.
\end{abstract}

Key words: prenatal, cognitive, physical, social, emotions

\begin{abstract}
Abstrak: Sampai saat ini masih ada beberapa orang yang menganggap bahwa perkembangan seorang anak dimulai ketika telah dilahirkan. Sebenarnya, perkembangan dapat diamati ketika tahap ovulasi. Mulai dari sini, perkembangan calon bayi sudah dapat diamati dan dipelajari. Pendidikan dalam kandungan sangat penting bagi anak karena pada masa itu anak mengalami perkembangan dan pertumbuhan awal. Saat dalam kandungan, ibu merupakan orang yang paling utama membentuk kecerdasan anak melalui pendidikan yang diberikan. Tujuan kajian ini yaitu untuk memberikan beberapa pengetahuan tentang perkembangan anak dimasa sebelum kelahiran atau prenatal. Kajian ini menggunakan metode Library Research dengan mengkaji beberapa sumber data dari buku-buku yang berkaitan dengan perkembangan pranatal. Kesimpulan dari kajian ini adalah perkembangan masa pranatal memiliki pengaruh yang sangat penting bagi perkembangan anak. Terdapat beberapa hal yang harus diperhatikan agar anak mengalami perkembangan yang sempurna, sehingga secara kognitif, fisik, dan emosi sosial anak dapat berkembang secara optimal.
\end{abstract}

Kata kunci: prenatal, kognitif, fisik, emosi, sosial 
Nurul Maziyatul H, Dewi Fahmi A, Avita Febri H, Perkembangan Kognitif, Fisik, Dan Emosi Sosial Pada Masa Prenatal

\section{PENDAHULUAN}

Secara parsial, psikologi perkembangan dapat dipecah menjadi beberapa subdisiplin, yaitu perkembangan masa prenatal, perkembangan anak, perkembangan remaja, perkembangan orang dewasa, dan gerontologi (psikologi perkembangan yang mempelajari masa usia lanjut). ${ }^{1}$ Dengan demikian, ruang lingkup psikologi perkembangan dimulai sejak masa konsepsi sampai manusia meninggal.

Proses pendidikan yang tepat bermula dari persiapan yang baik dan matang. Jika langkah-langkah awal kedatangannya sudah dipersiapkan dengan benar, maka ini bisa menjadi sebuah permulaan yang baik bagi proses menghasilkan generasi penerus yang berkualitas. ${ }^{2}$ Pendidikan telah menjadi unsur yang begitu penting bagi perkembangan kehidupan manusia. ${ }^{3}$ Sehingga pendidikan sebaiknya dilakukan secara terus menerus atau secara berkesinambungan, mulai dari anak masih di dalam kandungan sampai dewasa akhir.

Pendidikan anak di dalam kandungan sangat penting karena pada masa itu, anak mengalami perkembangan dan pertumbuhan awal yang baru mulai terbentuk. Pada masa anak di dalam kandungan, ibu merupakan orang yang paling utama membentuk kecerdasan anak melalui pendidikan yang diberikan.

Kondisi lbu yang mengandung janin harus benar-benar terjaga dengan baik dan anak yang berada dalam masa anak usia dini juga harus benar dijaga dari kondisi lingkungan sekitar, karena masa anak usia dini anak sangat peka terhadap kondisi perasaan lingkungan sekitar. ${ }^{4}$ Sehigga kondisi kesehatan ibu juga sangat berpengaruh kepada keadaan bayi di

${ }^{1}$ Rosleny Marliani, Psikologi Perkembangan, Bandung: CV Pustaka Setia, 2015:91.

${ }^{2}$ Ria Riksani, Dari Rahim Hingga Besar Mendidik Buah Hati Menuju Ridha Ilahi, Jakarta: Elex Media Komputindo, 2013:1.

${ }^{3}$ Uhbayati, Nur. Long Life Education: Pendidikan Anak Sejak Dalam Kandungan Sampai Lansia. Semarang: Walisongo Press, 2009:3.

${ }^{4}$ Fatih, Muhamad. Implementasi Profetik Prenatal dan PAUD, Al Hikmah: Indonesian Journal Of Early Childhood Islamic Education, 2020:20. 
dalam kandungan. Banyak kondisi anak setelah lahir yang mengalami gangguan kesehatan baik fisik maupun psikologis karena pada saat anak di dalam kandungan, ibu dan orang di sekitar anak tersebut mengabaikan kondisi kesehatan ibu dan kandungannya serta tidak memberikan pendidikan kepada anak pada masa di dalam kandungan. Seperti bayi mengalami premature, berat badan rendah, disabilitas bahkan hingga kematian. ${ }^{5}$ Melihat dampak buruk tersebut maka seharusnya pendidikan harus dimulai sejak masa prenatal, sehingga secara kognitif, fisik, dan emosi sosial anak dapat berkembang secara optimal dan siap ketika memasuki jenjang selanjutnya.

Upaya orang-orang di sekitar calon bayi sangat berpengaruh dan penting, sehingga pendidikan prenatal atau pendidikan di dalam kandungan serta metode-metode yang perlu dilakukan oleh keluarga dan orang-orang di sekitar calon bayi. Untuk memahami bagaimana perkembangan kognitif, fisik dan emosi sosial pada masa prenatal, serta faktor dan dampaknya yang harus dipahami bagi semua calon orangtua, maka dari itu artikel ini akan dibahas mengenai perkembangan kognitif, fisik dan emosi sosial pada masa prenatal.

\section{Pengertian Prenatal}

Secara umum pengertian prenatal berasal dari kata pra yang berarti sebelum dan natal yang berarti lahir. Jadi pengertian prenatal adalah sebelum kelahiran, yang berkaitan dengan hal-hal atau keadaan sebelum melahirkan. ${ }^{6}$ Masa prenatal adalah periode perkembangan pertama jangka kehidupan manusia dan secara biologis, hidup dimulai pada waktu ini. Periode ini dimulai pada waktu konsepsi, yaitu pembuahan dari ovum oleh sel sperma, dan berakhir pada waktu kelahiran. Menurut pendapat yang masyhur, rentang waktu tersebut adalah 9 bulan 10 hari, atau 280 hari.

\footnotetext{
${ }^{5}$ Aprilia, Wahyu. Perkembangan pada Masa Pranatal dan Kelahiran, Yaa Bunayya: Jurnal Pendidikan Anak Usia Dini, 2020: 47.

6Mansur, Mendidik Anak Sejak Dalam Kandungan Kado Buat Pengantin Baru, Calon Ibu dan Ibu Hamil, Yogyakarta: Mitra Pustaka, 2009:36.
} 
Nurul Maziyatul H, Dewi Fahmi A, Avita Febri H, Perkembangan Kognitif, Fisik, Dan Emosi Sosial Pada Masa Prenatal

Tetapi ada kalanya kurang atau sebaliknya lebih, tergantung kepada situasi dan kondisi serta berbagai faktor yang mempengaruhinya. ${ }^{7}$

Menurut William Sallenbach dalam buku Psikologi Perkembangan, periode prenatal atau pralahir merupakan masa kritis bagi perkembangan fisik, emosi dan mental bayi. Ini adalah masa ketika kedekatan hubungan antara bayi dan orang tua mulai terbentuk dengan konsekuensi yang akan berdampak panjang, terutama berkaitan dengan kemampuan dan kecerdasan bayi dalam kandungan. ${ }^{8}$

Meskipun kenyataan bahwa periode perkembangan pertama dalam rentang kehidupan ini merupakan periode yang paling singkat dari seluruh periode perkembangan, namun dalam banyak hal periode ini penting atau bahkan yang terpenting dari semua periode. Periode ini, yang mulai pada saat pembuahan dan berakhir pada kelahiran, kurang lebih panjangnya 270 sampai 280 hari atau sembilan bulan. Meskipun relatif singkat, periode pranatal mempunyai enam ciri penting, masing-masing ciri mempunyai akibat yang lambat pada perkembangan selama rentang kehidupan. Ciriciri itu adalah:

1. Pada saat sifat-sifat bauran, yang berfungsi sebagai dasar bagi perkembangan selanjutnya, diturunkan sekali untuk selamanya. Sementara itu kondisi-kondisi yang baik atau tidak baik, baik sebelum atau sesudah kelahiran sampai tingkat tertentu, dapat dan mungkin mempengaruhi sifat-sifat fisik dan psikologis yang membentuk sifat-sifat bawaan ini, perubahan-perubahan yang terjadi bersifat kuantitatif dan bukan kualitatif.

2. Kondisi-kondisi yang baik dalam tubuh ibu dapat menunjang perkembangan sifat bawaan sedangkan kondisi yang tidak baik dapat menghambat perkembangannya bahkan sampai mengganggu pola perkembangan yang akan datang. Ada saatnya dalam rentang

${ }^{7}$ Elfi Yuliani Rochmah, Psikologi Perkembangan, Yogyakarta: Teras, 2005:89.

${ }^{8}$ Rosleny Marliani...,2015:93. 
kehidupan sifat bawaan sangat dipengaruhi kondisi-kondisi lingkungan seperti halnya selama periode pranatal.

3. Jenis kelamin individu yang baru diciptakan sudah dipastikan pada saat pembuahan dan kondisi-kondisi dalam tubuh ibu tidak akan mempengaruhinya, sama halnya dengan sifat bawaan kecuali kalau dilakukan pembedahan dalam operasi perubahan kelamin, jenis kelamin individu yang sudah ditetapkan pada saat pembuahan tidak akan berubah. Operasi semacam itu sangat jarang dilakukan dan hanya sebagian kecil saja berhasil.

4. Perkembangan dan pertumbuhan yang normal lebih banyak terjadi selama periode prenatal dibandingkan pada periode-periode lain dalam seluruh kehidupan individu. Selama Sembilan bulan sebelum kelahiran, individu tumbuh dari sel kecil yang tampak dari mikroskop menjadi bayi yang panjangnya sekitar dua puluh inci dan beratnya rata-rata 7 ons. Diperkirakan bahwa selama masa itu berat badan bertambah sebelas juta kali. Demikian pula, halnya dengan perkembangan yang kelihatannya berlangsung begitu cepat. Dari sebuah sel berbentuk bulat pada masa itu berkembanglah setiap anggota tubuh manusia, baik eksternal maupun internal. Pada waktu kelahiran, bayi dapat dikenali sebagai manusia, meskipun banyak ciri-ciri eksternalnya secara proposional berbeda dengan ciri-ciri anak yang lebih tua usianya, dengan anak remaja atau dengan seorang dewasa.

5. Periode prenatal merupakan masa yang mengandung banyak bahaya, baik fisik maupun psikologis, meskipun tidak dapat diklaim bahwa periode ini merupakan periode yang paling berbahaya dalam seluruh rentang kehidupan banyak yang percaya bahwa masa anakanak lebuh berbahaya tetapi jelas bahwa periode ini merupakan masa dimana bahaya-bahaya lingkungan atau bahaya-bahaya psikologis dapat sangat mempengaruhi pola perkembangan selanjutnya atau bahkan dapat mengakhiri suatu perkembangan. 
Nurul Maziyatul H, Dewi Fahmi A, Avita Febri H, Perkembangan Kognitif, Fisik, Dan Emosi Sosial Pada Masa Prenatal

6. Periode prenatal merupakan dimana orang-orang yang berkepentingan membentuk sikap-sikap pada diri individu yang baru diciptakan. Sikap-sikap ini akan sangat mempengaruhi cara bagaimana individu-individu ini diperlakukan, terutama selama tahun-tahun pertama pembentukan kepribadiannya. Kalau sikapsikap ini sangat bersifat emosional, maka hal ini dapat dan seringkali merusak keseimbangan ibu (mother's homeostasis), dan dengan demikian mengganggu kondisi-kondisi di dalam tubuh ibu yang sangat penting bagi perkembangan normal dari individu yang baru diciptakan. $^{9}$

Menurut Paul Henry Mussen menjelaskan dengan bahasa berbeda bahwa perkembangan masa prenatal dibagi menjadi tiga periode berikut:

1. Periode zigot (sejak pembuahan sampai akhir minggu ke-2). Periode ini berlangsung dari pembuahan sampai implementasi pada dinding Rahim, sekitar 10 hari setelah pembuahan. Jika sperma memasuki ovum, terjadi peleburan inti sperma dengan inti ovum yang telah dibuahi yang disebut zigot (yang mengandung 23 kromosom). Kemudian, ovum yang telah dibuahi mulai membelah diri (melakukan pembelahan), dari saluran sel telur tempat ia dibuahi menuju uterus dan akan ditanam (menempel) di dinding uterus (implantasi).

2. Periode embrio (akhir minggu ke-2 sampai akhir bulan ke-2 berdasarkan hitungan bulan). Periode ini ditandai dengan perkembangan yang cepat sekali dari susunan saraf. Pada periode ini kepala lebih besar dibandingkan dengan bagian badan yang lain. Ini menunjukkan 8 minggu yang pertama merupakan suatu periode yang sensitif untuk integritas susunan saraf.

${ }^{9}$ Elizabeth B. Hurlock, Psikologi Perkembangan Suatu Pendekatan Sepanjang Rentang Kehidupan Edisi Kelima, terjemahan Development Psychology A Live-Span Approach, Fifth Edition oleh Istiwidayanti dan Soedjarwo, Jakarta: Erlangga, 1991:28. 
3. Periode janin atau fetus (akhir bulan ke-2). Periode ini berlangsung dari akhir bulan ke-2 sampai lahir. ${ }^{10}$

Dalam pandangan Islam, fase prenatal (sebelum lahir) dimulai sejak masa konsepsi sampai proses kelahiran, yaitu sekitar 9 bulan sampai 280 hari. Sebagaimana di sebutkan dalam QS. Al-Mu'minun ayat 12-16, yaitu:

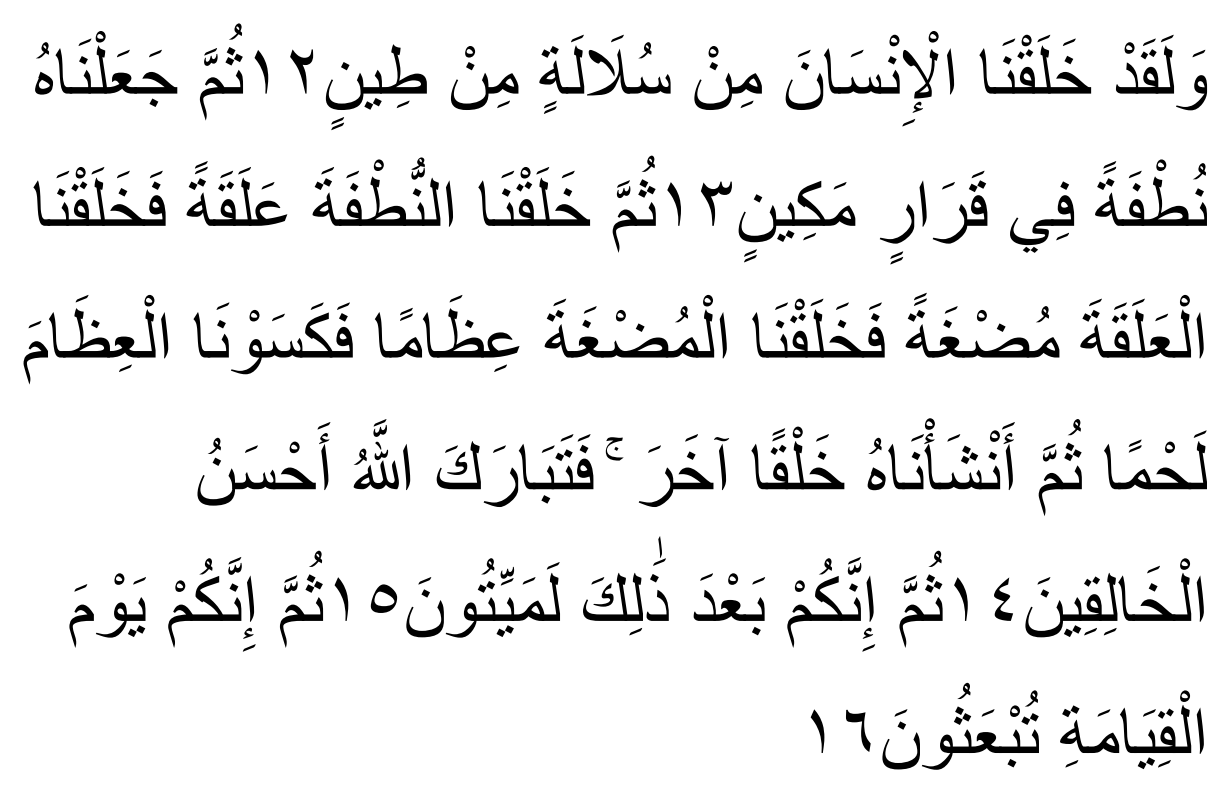

Artinya:

Dan sesungguhnya Kami telah menciptakan manusia dari suatu saripati (berasal) dari tanah. Kemudian Kami jadikan saripati itu air mani (yang disimpan) dalam tempat yang kokoh (rahim). Kemudian air mani itu Kami jadikan segumpal darah, lalu segumpal darah itu Kami jadikan segumpal daging, dan segumpal daging itu Kami jadikan tulang belulang, lalu tulang belulang itu Kami bungkus dengan daging. Kemudian Kami jadikan dia makhluk yang (berbentuk) lain. Maka Maha sucilah Allah, Pencipta Yang Paling Baik. Kemudian, sesudah itu, sesungguhnya kamu sekalian benarbenar akan mati. Kemudian, sesungguhnya kamu sekalian akan dibangkitkan (dari kuburmu) di hari kiamat.

${ }^{10}$ Rosleny Marliani..., 2015:101. 
Nurul Maziyatul H, Dewi Fahmi A, Avita Febri H, Perkembangan Kognitif, Fisik, Dan Emosi Sosial Pada Masa Prenatal

Ayat di atas merinci dengan jelas pertumbuhan dan perkembangan manusia prenatal, yaitu 1) Fase nuthfah (tetesan sperma, spermatozoa), 2) Fase 'alaqah atau fase gumpalan darah atau yang melekat pada dinding uterus atau Rahim, 3) Fase mudhghah (gumpalan daging), 4) Fase terbentuknya tulang ('idzam) yang terbalut oleh daging, jaringan, dan otot, 5) Fase janin dalam bentuk sempurna. ${ }^{11}$

Masa prenatal adalah masa ketika anak masih di dalam kandungan ibu. Masa ini memang masa yang sangat singkat di bandingkan masa rentang kehidupan manusia setelah anak lahir ke dunia. Masa prenatal hanya berlangsung selama 9 bulan, 10 hari, namun ada juga yang hanya berlangsung selama 7 bulan dan biasanya anak yang lahir pada usia 7 bulan dikatakan anak lahir prematur. Pada masa prenatal ini, diharapkan ibu yang sedang mengandung harus memperhatikan kesehatan gizi dan asupan makanan yang masuk ke dalam tubuh serta memberikan pendidikan untuk bayi yang masih berada di dalam kandungan.

\section{Perkembangan Prenatal dari Segi Kognitif}

1. Perkembangan dalam belajar dan mengingat yaitu perkembangan belajar janin telah diketahui ketika dia mengisap jari di dalam rahim. Sementara perkembangan mengingat diketahui ketika bayi merekam setiap pembicaraan ibunya, atau ketika ibu sedang membacakan ceritacerita dengan keras pada masa kehamilan. Membacakan cerita-cerita dengan suara keras lebih mengaktifkan rekaman ingatan bayi ketimbang ibu yang sama sekali tak pernah membacakan cerita pada masa kehamilan. ${ }^{12}$

2. Perkembangan kognitif anak dalam kandungan, di mana menurut laporan para ilmuwan dalam bidang perkembangan anak pralahir yang melakukan beberapa penelitian mutakhir makin menguatkan dugaan bahwa anak dapat belajar selama berada dalam Rahim ibunya. Dia juga

\footnotetext{
${ }^{11}$ Rosleny Marlian,..., 2015:101-102

${ }^{12}$ Herri Zan Pieter dan Namora Lumongga Lubis, Pengantar Psikologi untuk Kebidanan Edisi Revisi, Jakarta: Prenadamedia Group, 2016:69.
} 
bisa merasa, dan mengetahui perbedaan antara gelap dan terang. Bahkan pada usia kandungan lima bulan (20 pekan), kemampuan bayi dalam kandungan untuk merasakan rangsangan telah berkembang dengan sangat baik sehingga proses pendidikan dapat dilakukan. Dan anak-anak yang diberi pendidikan sejak masih dalam kandungan cenderung mengalami peningkatan kecerdasan otak, mampu berkomunikasi lebih baik dan mudah beradaptasi dengan lingkungan ketika besar nanti. ${ }^{13}$ Pentingnya pemberian rangsangan sejak dini merupakan satu hal yang perlu diberikan kepada anak untuk meningkatkan tingkat intelektual dan tingkat kreativitas anak. ${ }^{14}$

\section{Perkembangan Prenatal dari Segi Fisik}

1. Periode Germinal (zygote);periode ini berlangsung sejak ovum dibuahi hingga 10-14 hari. Periode ini meliputi terjadinya zygote yang dilanjutkan dengan pembelahan sel dan terjadilah implantation. Implantation ialah menempelnya zygote pada dinding uterus yang berlangsung sekitar 10 hari setelah pembuahan. Satu minggu setelah pembuahan, zygote melakukan pembelahan sel yang telah dimulai ketika lapisan dalam (blastocyt) dan lapisan luar (trophoblast) organisme terbentuk. Pada lapisan dalam sel (blastocyt) akan berkembang terus menjadi embrio. Lapisan luar (trophoblast) akan berkembang menjadi lasenta (ari-ari) yang menjadi pelindung embrio, tali pusar, dan amnion yang menyediakan gizi bagi embrio. Periode zygote sering juga disebut sebagai periode conceptual.

2. Periode Embryonicyaitu suatu periode kehamilan dengan rentang usia antara akhir minggu ke-2 sampai dengan akhir minggu ke-8, ditandai dengan perkembangan yang pesat pada organ tubuh, sistem pernapasan, pencernaan, dan saraf. Pada masa ini terjadi diferensiasi

\footnotetext{
${ }^{13}$ Briliantono M. Soenarwo, 360 Pekan Masa Keemasan Anak; Sekali Seumur Hidup, Jakarta: Halimun Medikal Centre dan Al-Mawardi Prima, 2012: 54-56

${ }^{14}$ Anik Pamilu, Mendidik Anak Sejak dalam Kandungan (Pandangan Lengkap Cara Mendidik Anak Untuk Orang tua), Yogyakarta: Citra Media, 2007:12-13
} 
Nurul Maziyatul H, Dewi Fahmi A, Avita Febri H, Perkembangan Kognitif, Fisik, Dan Emosi Sosial Pada Masa Prenatal

sel. System saraf berkembang pada usia akhir minggu ketiga jantung mulai berdetak, kemudian embrio terus berkembang dan pada akhirnya menjadi janin sebagai bentuk manusia kecil yang ditandai pembentukan kepala $11 / 4$ ons dengan panjang sekitar $1 \frac{1}{2}$ inci $(2,5 \mathrm{~cm})$. periode embrionis merupakan periode yang sangat rentan terjadinya keguguran spontan.

3. Periode Fetus yaitu suatu periode kehamilan dengan rentang usia akhir minggu ke-8 sampai awal kelahiran. Fetus bertumbuh dengan cepat dan diperkirakan panjangnya kira-kira 20 kali dari sebelumnya. System organ-organ dan tubuh semakin kompleks. Pada periode ini janin sangat aktif. Gerakan-gerakan janin pertama kali terjadi pada minggu ke 18-21, di mana fetus sudah mampu melakukan gerakan, seperti tersenyum,mengisap, merengut atau menelan.pada periode fetus ini tidak ada pembentukan organ-organ tubuh yang baru. Pada akhir bulan ke-3 organ-organ bagian dalam berkembang dan berfungsi. Detak jantung janin diketahui sekitar minggu ke-15. Pada akhir bulan ke-7 janin sudah bisa dilahirkan meski pun belum cukup umur. ${ }^{15}$

Selanjutnya terdapat tahap-tahap perkembangan fisik prenatal yaitu:

1. Bulan pertama (0-4 minggu), yaitu sepuluh hari setelah konsepsi sel telur yang telah dibuahi embrio akan bergerak turun dari ujung saluran telur menuju Rahim dan akhirnya membenamkan diri ke dinding Rahim. Pembentukan konsepsi yang ditandai terlambat haid dua minggu. Kemudian zygote akan membentuk lapisan luar dan lapisan dalam. Lapisan luar berkembang menjadi plasenta dan lapisan dalam menjadi janin. Lapisan dalam terdiri dari tiga bagian yang terpisah, yaitu lapisan bagian terluar menjadi saraf dan kulit janin, lapisan tengah menjadi tulang, tulang rawan, otot, sistem sirkulasi ginjal dan seks. Adapun pada lapisan terdalam menjadi organ pernapasan dan pencernaan janin. Ciriciri lain pertumbuhan dan perkembangan ialah pertumbuhan otak,

15 Herri Zan Pieter dan Namora Lumongga Lubis ..., 2016:63-64. 
susunan saraf tulang belakang, dan wajah mulai terbentuk. Panjang janin diperkirakan sekitar $2 \mathrm{~cm}$.

2. Bulan kedua (4-8 minggu), pada usia ini tulang punggung, sistem saraf, otak mulai berkembang dan diikuti dengan pertumbuhan tonjolan jantung. Pada usia ini jantung telah terbentuk dalam rongga dada dan mulai berdetak. Jantung mulai memompa darah ke seluruh embrio. Saat memasuki usia tujuh minggu bagian wajah sudah mulai tumbuh, seperti hidung, bibir, lidah, dan gigi. Berbagai tunas dari sejumlah organ tubuh mulai timbul. Otak berkembang pesat ditandai adanya pada pembentukan sel-sel saraf dan pembuuh darah. Selain itu, mulai ada pembentukan tulangpunggung dan warna mata, jari-jari dan kaki. Panjang janin diperkirakan $2,5 \mathrm{~cm}$.

3. Bulan ketiga (8-12 minggu), di mana bentuk janin semakin mirip dengan bentuk bayi. Saat ini janin relatif aman dari infeksi. Gerakangerakan halus janin mulai dirasakan ibu ketika usia 18-20 minggu. Bahkan janin sudah mulai melakukan gerakan-gerakan salto, membalikkan tubuh dan membuat kepalan tinju. Janin sudah bisa menunjukkan ekspresi wajahnya. Detak jantung berkisaran 110-160 kali permenit. Jari-jari tangan dan kakinya sudah terbentuk dengan sempurna. Kini berat janin sekitar 8gr. Ciri-ciri perkembangan fisik lain adalah ukuran kepala lebih besar dari tubuh, di mana otak terus tumbuh, selain itu juga sudah ada pembentukan dagu, hidung, dan kelopak mata. Kini panjang janin sekitar $9 \mathrm{~cm}$.

4. Bulan keempat (12-16 minggu) yaitu kerangka janin berkembang semakin proposional. Kaki lebih panjang dri tangan. Rambut kepala bertambah tebal, mulai tumbuh bulu-bulu mata dan kini berat janinkirakira 100gr. Tubuh bayi dibungkus oleh rambut-rambut halus (lanugo) yang berfungsi menjaga janin dalam suhu yang seimbang. Sekujur tubuh janin dilapisi senyawa putih berminyak atau vernix. Pada usia 14 minggu hampir seluruh otot besar janin mulai merespons pesan yang diperintahkan otak, seperti janin mulai dapat menekuk lengan, 
Nurul Maziyatul H, Dewi Fahmi A, Avita Febri H, Perkembangan Kognitif, Fisik, Dan Emosi Sosial Pada Masa Prenatal

pergelangan tangan, dan jari-jari telah mampu untuk ditekuk dan dikepal. Kulit, otot, dan anggota tubuh terbentuk sesuai tempatnya. Janin sudah bisa mendengarkan suara detakan jantung ibunya yang diikuti dengan adanya ekspresi wajah, dapat mengubah posisi kepala dan membuka mulut. Kini panjang janin diperkirakan sekitar $16-18 \mathrm{~cm}$.

5. Bulan kelima (16-20 minggu), yaitu memasuki minggu ke-16 janin mulai mengisap jari jempolnya. Kemampuan mengisap dan menelan berfungsi sebagai awal belajar janin terhadap keterampilan makan kemudian hari. Kini kantong amnion semakin sempit sehingga ibu semakin merasakan gerakan-gerakan janin. Untuk memperoleh kebutuhan nutrisi, janin minum cairan amnion setiap hari. Cairan ini diperoleh melalui melalui sistem pencernaan. Nutrisi yang terkandung dalam cairan amnion akan diserap dalam tubuh janin dan janin akan menyimpan bahan makanan padat di ususnya. Cairan zat sampah diolah ginjal, kemudian akan dikeluarkan berupa tetesan air seni. Gigi susu dan tunas gigi semakin berkembang.Memasuki kegiatan kelima ini kegiatan janin mulai teratur, seperti keteraturan waktu bangun dan waktu tidur. Janin hanya bergerak sesekali saat tidur. Pada usia bulan kelima hampir seluruh sistem dalam tubuh janin sudah mulai menjalankan tugasnya, seperti sistem saraf. Demikian pula halnya dengan jantung, di mana kini jantung sudah bekerja sekali pun cara kerjanya tergolong belum sempurna. Pada usia bulan ke-5 jenis kelamin janin sudah diketahui. Jika janinnya laki-laki akan terlihat skrotum (buah jakar) dan bila janinnya perempuan akan terlihat vagina. Sel-sel darah putih mulai terbentuk. Sel putih berfungsi melawan penyakit dan infeksi. Kulit janin makin tebal dan tidak tembus cahaya. Janin sudah mampu mendengarkan suara ibunya dan bisa membedakan rasa pahit dan manis. Kini panjang janin diperkirakan 25 $\mathrm{cm}$.

6. Bulan keenam (20-24 minggu), pada bulan ini melalui stetoskop, yaitu suatu metode deteksi dengan menempelkan telinga diperut ibu, 
diketahui bahwa detak jantung bayi bisa didengar. Detak jantung janin berkisar 159 kali per menit. Pada periode ini janin sudah bisa mendengarkan suara ibunya dan orang lain dengan jelas. Kini sel-sel otak janin yang makin berkembang dan semakin rumit. Pada periode ini janin juga terus berlatih pernapasan. Pada usia keenam kelopak mata sudah dapat mbuka dan menutup. Pembentukan daun teliga semakin terlihat jelas. Janin mulai mampu mendengarkan suara-suara di lingkungan Rahim, seperti suara-suara organ tubuh bagian dalam yang sedang beraktivitas. Kini otot-otot tubuh semakin kuat diikuti dengan pembentukan dan perkembangan tulang-tulang tubuh akan semakin keras. Panjang janin diperkirakan sekitar $39 \mathrm{~cm}$.

7. Bulan ketujuh (24-28 minggu), pada usia ini, bobot janin semakin bertambah berat dan berisi. Rambut halus masih tampak di sekujur tubuhnya. Paru-paru dan otak janin belum berkembang sempurna, tetapi saraf dan jaringan saraf sudah berfungsi. Otak terus mengalami perkembangan pesat dan diikuti dengan pertumbuhan jutaan sel saraf otak janin. Jaringan-jaringan kulit janin mulai dialiri pembuluh darah kapiler sehingga kulit janin tampak berwarna kemerahan. Janin sudah bisa merasakan nyeri. Kini ibu merasakan gerakan janin yang berpindah-pindah. Ketika keadaan normal kepala janin selalu selalu berada di bawah, sehingga terkadang janin sudah mempersiapkan diri untuk dilahirkan. Memasuki 33 minggu, kuku jari-jari tangan dan kaki tumbuh sempurna. Kelopak mata sudah ditumbuhi bulu-bulu mata dan sudah membuka dan menutup mata. Oksigen yang dibutuhkan masih disuplai dari tubuh ibu melalui aliran darah pada tali pusar. Denyut jantung lebih cepat ketika ibu sedang berbicara. Kini berat janin 2 kg dengan panjang $35 \mathrm{~cm}$.

8. Bulan kedelapan (28-32 minggu), pada usia ini janin terlihat lebih montok dan hampir memenuhi Rahim sehingga ibu merasa sesak. Gerakan-gerakan bayi mulai terbatas dan sudah tidak bisa lagi jungkir balik dalam Rahim. Rambut-rambut halus yang berfungsi 
Nurul Maziyatul H, Dewi Fahmi A, Avita Febri H, Perkembangan Kognitif, Fisik, Dan Emosi Sosial Pada Masa Prenatal

melindunginya mulai rontok. Janin memproduksi hormon krostisom yang dapat membantu menyempurnakan pembentukan paru-paru agar janin siap bernapas saat dilahirkan. Kini struktur tubuh bayi semakin lengkap, mampu mengedipkan mata dan melihat cahaya melalui dinding perut ibu berat badan bertambah membuat gerakannya terbatas. Kini panjang janin sekitar $45 \mathrm{~cm}$ dan berat janin rata-rata 2,75 kg.Selain itu pada trisemester kedua pendengaran janin semakin sempurna. Sehingga mampu mendengarkan suara-suara ibunya dan suara di lingkungan luar. Dasar teori inilah sehingga muncul konsep awal berkomunikasi dengan baik kepada janin. Akhir bulan ke-8 kepala janin sudah berada di dalam rongga panggul dan siapdilahirkan. Sistem saraf sudah berkembang sempurna dan janin membekali diri dengan keterampilan untuk bernapas dan menelan.

9. Bulan kesembilan (32-36 minggu), pada periode ini penambahan lemak sebanyak 14 kali setiap harinya yang di bawah permukaan kulitnya. Panjang rambut sekitar $5 \mathrm{~cm}$. adanya keterbatasan tempat dalam rahim membuat bayi jarang bergerak. Pada usia 39 minggu, janin sudah dapat menjalankan fungsi tubuhnya. Sistem pencernaan berfungsi, namun masih berjalan lamban. Kini usus kecil dipenuhi mekonium (tinja awal). Pada umumnya posisi bayi berada pada posisi siap dilahirkan. Kini janin turun menempati rongga panggul. Vernix dan amnion mulai larut. Rambut-rambut halus pada tubuh mulai hilang. Berat badan sekitar $3 \mathrm{~kg}$ dan panjang janin sekitar $50 \mathrm{~cm} .{ }^{16}$

\section{Perkembangan Prenatal dari Segi Emosi-Sosial}

Berkomunikasi dengan buah hati tidak hanya bisa dilakukan setelah bayi lahir dan bisa berbicara. Namun, sebetulnya komunikasi antara ibu dan janin, lingkungan dengan janin sudah dimulai tercipta sejak dalam kandungan. Tanpa banyak disadari, ibu dan janin sudah memiliki hubungan emosional yang sangat kuat. Biasanya dimulai sejak usia kehamilan enam

${ }^{16}$ Herri Zan Pieter dan Namora Lumongga Lubis..., 2016:64-68 
bulan. Janin sudah bisa merasakan emosi ibu, baik saat senang atau sedih melalui hormon ibu yang disalurkan kedalam tubuh janin. Tentu kesempatan berharga untuk menjalin kedekatan secara emosional dengan buah hati tidak boleh dilewatkan. ${ }^{17}$

Beberapa pakar anak mengemukakan bahwa jika janin dalam kandungan secara terus-menerus mendapatkan stimulasi (rangsangan) positif, maka kelak anak tersebut akan menjadi anak yang lebih cepat perkembangan otaknya jika dibandingkan dengan teman-temanya yang tidak mendapatkan stimulasi saat masih dalam kandungan. Pada umumnya seorang anak telah memiliki ikatan atau jalinan yang kuat dengan ibu, walaupun masih dalam kandungan. Berbagai cara yang dapat dilakukan untuk memberi stimulasi pada janin, diantaranya sebagai berikut 1) Membelai, menepuk, dan mengusap dengan lembut, 2) Mengajak bicara, 3) Mendongengkan. ${ }^{18}$

Selain memberi stimulus, keadaan emosional ibu selama kehamilan juga mempunyai pengaruh yang besar terhadap perkembangan masa prenatal. Hal ini dikarenakan ketika seorang ibu hamil mengalami ketakutan, kecemasan, stres dan emosi lain yang mendalam, maka terjadi perubahan psikologis, antara lain yang meningkatnya pernapasan dan sekresi oleh kelenjar. Adanya produksi hormon andrenalin sebagai tanggapan terhadap ketakutan akan menghambat aliran darah ke daerah kandungan dan membuat janin janin kekurangan udara. ${ }^{19}$

Ibu yang mengalami kecemasan berat dan berkepanjangan sebelum atau selama kehamilan, kemungkinan besar mengalami kesulitan medis dan melahirkan bayi yang abnormal dibandingkan dengan ibu yang relatif tenang dan aman. Goncangan emosi diasosiasikan dengan kejadian aborsi spontan, kesulitan proses lahir, kelahiran prematur dan penurunan berat, kesulitan pernapasan dari bayi yang baru lahir dan cacat fisik. ${ }^{20}$

\footnotetext{
${ }^{17}$ Ria Riksani...., 2013:24.

${ }^{18} \mathrm{lbid}$.

${ }^{19}$ Desmita, Psikologi Perkembangan, Bandung: PT Remaja Rosdakarya, 2005: 85.

${ }^{20} \mathrm{lbid}$
} 
Nurul Maziyatul H, Dewi Fahmi A, Avita Febri H, Perkembangan Kognitif, Fisik, Dan Emosi Sosial Pada Masa Prenatal

Disamping itu, stres dan kecemasan yang dialami ibu setelah kehamilan, diasosiasikan dengan bayi yang sangat aktif lekas marah (pemarah), dan tidak teratur dalam makan, tidur, dan buang air. Kecemasan pada ibu itu kemungkinan terus berlanjut sampai setelah anak lahir. Suatu studi memperlihatkan hubungan antara kecemasan ibu selama kehamilan dan kondisi bayi yang baru lahir. Dalam studi ini, ibu-ibu menjawab suatu kuesioner tentang kecemasan mereka setiap 3 bulan selama kehamilan. Ketika bayi sudah lahir, berat bayi, tingkat aktivitas, dan tangisannya diukur. Bayi dari ibu yang lebih cemas menangis lebih banyak sebelum diberi makan dan lebih aktif daripada bayi yang dilahirkan oleh ibu-ibu yang kurang cemas. ${ }^{21}$

Bahaya psikologis dapat menimbulkan akibat yang tetap ada pada perkembangan individu dan dapat mempengaruhi lingkungan sesudah dilahirkan dan perlakuan yang diterima anak dari orang-orang yang berarti selama tahun-tahun pertumbuhan awal. Tiga bahaya psikologis yang penting berupa:

1. Kecepercayaan tradisional yaitu kepercayaan yang lebih tradisional dan lebih merusak mengenai periode perkembangan pranatal daripada kepercayaan mengenai periode-periode lain dalam rentang kehidupan. Kepercayaan demikian dapat dan memang mempengaruhi perlakuan orang tua kepada anak-anaknya dan seringkali mempengaruhi sikap anak satu terhadap anak yang lainnya. Meskipun sejumlah temuan ilmiah membuktikan sebaliknya, tetapi banyak orang, misalnya masih percaya bahwa penentuan jenis kelamin anak dapat mereka kendalikan. Kepercayaan tradisional tentang bagaimana seseorang dapat meramalkan jenis kelamin anak yang belum lahir juga dapat mengakibatkan kebencian dan kekecewaan yang terungkap dalam sikap yang kurang menyenangkan terhadap anak, hal ini seringkali tetap ada selama hidupnya. Kalau misalnya dipercaya bahwa para

${ }^{21}$ Desmita..., 2005:85. 
dokter dapat meramalkan dengan 100\% jenis kelamin anak yang belum lahir melalui tes denyut jantung atau tes air liur, orangtua seringkali sangat kecewa kalau jenis kelamin anak yang dilahirkan ternyata berbeda dengan apa yang diramalkan. Sampai sekarang, cara cara meramal jenis kelamin anak yang belum lahir dengan ketepatan yang tinggi hanyalah melalui tes amniocentesis. ${ }^{22}$

2. Tekanan yang dialami ibu, banyak hal yang menyebabkan tekanan pada ibu selama kehemilan, dan yang sangat sering timbul adalah: tidak menghendaki kehadiran anak karena adanya kesulitan dalam perkawinan atau keuangan atau karena kelahiran anak akan mengganggu program pendidikan ataupun pekerjaan, gangguangangguan fisik yang berat dan yang cukup sering terjadi sehingga menjadikan calon ibu gelisah, cepat marah, dan umumnya mengalami gangguan emosi, merasa kurang sesuai dalam peran sebagai orangtua, takut kalau anaknya akan mengalami cacat fisik atau keterbelakangan mental, karena seringkali ditingkatkan oleh adanya laporan media massa mengenai seringnya terjadi cacat lahir dan penyebab khusus cacat itu, seperti rubella dan thalidomide. ${ }^{23}$ Tekanan ibu mempengaruhi anak yang sedang berkembang baik sebelum maupun sesudah kelahiran. Sebelum kelahiran, adanya ketidakseimbangan kelenjar yang hebat dan menetap karena tekanan tersebut dapat mengakibatkan ketidak teraturan dalam perkembangan anak dan komplikasi pada waktunya. Rasa bingung dan cemas mempengaruhi kontraksi uterine, sehingga proses kelahiran berlangsung lebi lama daripada yang normal dan kemungkinan terjadi komplikasi lebih besar karena bayi seringkali harus dilahirkan dengan menggunakan alat. Lagi pula rasa khawatir, cemas, sering mengakibatkan banyak makan dan pertambahan berat badan yang

\footnotetext{
${ }^{22}$ Elizabeth B. Hurlock, Psikologi Perkembangan Suatu Pendekatan Sepanjang Rentang Kehidupan, Jakarta: Erlangga, 1991:44. ${ }^{23}$ lbid.
} 
Nurul Maziyatul H, Dewi Fahmi A, Avita Febri H, Perkembangan Kognitif, Fisik, Dan Emosi Sosial Pada Masa Prenatal

berlebihan dalam kehamilan yang selanjutnya akan menyulitkan persalinan. ${ }^{24}$

\section{Sikap-sikap yang kurang menyenangkan di pihak orang-orang} yang berarti, efek yang paling serius dan paling mendalam, karena sekali setiap berkembang maka sikap itu cenderung mapan dan hanya ada sedikit sekali perubahan atau modifikasi. Terdapat bukti bahwa banyak sikap yang kurang menyenangkan mulai berkambang pada saat kemungkinan kelahirannya diketahui orangtua, saudara. Seperti anak yang tidak diinginkan, tidak menghendaki anak pada saat ini, lebih menyukai anak dengan jenis kelamin tertentu, konsep anak impian, tidak menginginkan anak-anak kembar, menginginkan pengguguran atau aborsi dan penghinaan kepada anak. ${ }^{25}$

\section{Faktor-Faktor yang Mempengaruhi Perkembangan Prenatal}

1. Teratogen yaitu unsur yang menyebabkan adanya kelainan pada kelahiran akibat dari proses kehamilan yang tidak optimal. Bila teratogen beraksi pada awal kehamilan saat proses pembuahan dan organogenesis, bisa jadi berdampak negatif pada janin yang mengakibatkan kelainan anatomis. Namun, apabila teratogen beraksi pada saat organogenesis sudah lengkap dan matang di usia kehamilan tua, kemungkinan tidak menyebabkan kelainan anatomis. ${ }^{26}$

2. Faktor ibu, Ibu menjadi kunci utama yang sangat berpengaruh terhadap perkembangan janin. Sehingga kondisi fisik dan psikis ibu harus dijaga agar janin berkembang dengan sempurna. Selain itu, penyakit dan kondisi ibu selama kehamilan bisa mengakibatkan infeksi, kelainan dan kerusakan selama proses kehamilan yang mengakibatkan bayi lahir kurang sempurna. Beberapa penyakit yang dapat mempengaruhi janin, di antaranya, campak rubella, sifilis, herpes alat

\footnotetext{
${ }^{24}$ Elizabeth B. Hurlock, Psikologi Perkembangan Suatu Pendekatan Sepanjang Rentang Kehidupan...,1991:44.

${ }^{25}$ lbid..., 1991:45-46.

${ }^{26}$ Aprilia, Wahyu..., 2020: 44.
} 
kemaluan, dan AIDS. Selain dari penyakit, usia ibu juga mempengaruhi janin. Ibu yang hamil di usia beresiko yaitu saat remaja (dibawah 18 tahun) dan saat usia ibu sudah memasuki dewasa tengah (di atas 35). Bayi yang lahir dari ibu remaja, kebanyakan mengalami prematur dan keguguran. Pada ibu yang berusia paruh baya, kehamilan bisa berakibat keguguran, keterbelakangan mental pada bayi, dan komplikasi penyakit.

3. Faktor ayah, ayah juga berperan penting dalam perkembangan optimal janin. Perhatian dan kasih sayang seorang ayah kepada ibu akan membuat emosi ibu akan stabil, tenang dan bahagia. Stimulasi ayah pada janin dan sering mengajak bicara janin dalam kandungan juga dapat menenangkan janin, membangun ikatan emosional bayi dengan ayah dari suara dan sentuhan bayi, bisa berdampak pada perkembangan bahasa bayi. Selain itu, usia ayah yang sudah terlalu tua mengakibatkan anak kekurangan kalsium sehingga tinggi badannya kurang dan bisa mengakibatkan anak mengalami keterbelakangan mental seperti down syndrome

4. Lingkungan, Polusi dan bahan-bahan beracun yang semakin banyak di suatu lingkungan dapat membahayakan kondisi janin dalam kandungan dan berakibat keterbelakangan mental pada anak. Terkontaminasi polusi dan bahan-bahan beracun dapat mengakibatkan keterbelakangan mental pada anak. Ibu yang sedang mengandung sebaiknya sangat berhatihati dengan lingkungan dan apa yang akan di konsumsinya, karena jika ia mengkonsumsi makanan yang terkontaminasi bahan-bahan beracun dapat mengganggu perkembangan janin. ${ }^{27}$

${ }^{27}$ Aprilia, Wahyu..., 2020: 44. 
Nurul Maziyatul H, Dewi Fahmi A, Avita Febri H, Perkembangan Kognitif, Fisik, Dan Emosi Sosial Pada Masa Prenatal

\section{PEMBAHASAN}

Berdasarkan dari teori di atas bahwa perkembangan prenatal dari segi koginitif seperti ketika bayi mengisap jari di dalam rahim, ketika bayi merekam setiap pembicaraan ibunya, ketika ibu sedang membacakan cerita-cerita dengan keras pada masa kehamilan, serta merasa, dan mengetahui perbedaan antara gelap dan terang. Dari segi fisik, secara fisik Nampak bahwa setiap bulannya bayi mengalami perkembangan misalnya pada bulan pertama yaitu pertumbuhan otak, susunan saraf tulang belakang, dan wajah mulai terbentuk. Panjang janin $\pm 2 \mathrm{~cm}$. Bulan kedua yaitu usia ini tulang punggung, sistem saraf, otak, jantung mulai berkembang. Mulai tumbuh, hidung, bibir, lidah gigi warna mata, jari-jari dan kaki. Panjang janin 2,5 cm dan hingga bulan ke sembilan sehingga bayi siap untuk lahir. Dari segi emosi sosial tanpa banyak disadari, ibu dan janin sudah memiliki hubungan emosional yang sangat kuat. Janin bisa merasakan emosi ibu, baik saat senang atau sedih melalui hormon ibu yang disalurkan kedalam tubuh janin. Jika janin dalam kandungan secara terusmenerus mendapatkan stimulasi (rangsangan) positif, maka kelak anak tersebut akan menjadi anak yang lebih cepat perkembangan otaknya.

Selain itu terdapat faktor-faktor yang mempengaruhi perkembangan prenatal yaitu 1) Teratogen di mana unsur yang menyebabkan adanya kelainan pada kelahiran akibat dari proses kehamilan yang tidak optimal, 2) Faktor ibu, Ibu menjadi kunci utama yang sangat berpengaruh terhadap perkembangan janin. Sehingga kondisi fisik dan psikis ibu harus dijaga agar janin berkembang dengan sempurna. 3) Faktor ayah, di mana perhatian dan kasih sayang seorang ayah kepada ibu akan membuat emosi ibu akan stabil, tenang dan bahagia. 4) Lingkungan, Polusi dan bahan-bahan beracun yang semakin banyak di suatu lingkungan dapat membahayakan kondisi janin dalam kandungan dan berakibat keterbelakangan mental pada anak. 


\section{KESIMPULAN}

Dari pembahasan di atas dapat disimpulkan bahwa perkembangan manusia dimulai bukan ketika mereka dilahirkan ke dunia, melainkan telah di mulai sejak dari masa sebelum kelahiran. perkembangan prenatal dari segi kognitif, fisik, dan sosio emosi mengalami perkembangan tiap minggunya bahkan tanpa disadari oleh seorang ibu, seperti ketika bayi mengisap jari di dalam rahim, ketika bayi merekam setiap pembicaraan ibunya hal tersebut merupakan perkembangan prenatal dari segi kognitif, dari segi fisik seperti muncul berbagai organ tubuh seperti mata, hidung, tangan, kaki, berkembangnya organ tubuh, dan bertambahnya berat dan panjang bayi, selain itu dari segi sosial emosi yaitu janin bisa merasakan emosi ibu, baik saat senang atau sedih melalui hormon ibu yang disalurkan kedalam tubuh janin.

Selain itu juga terdapat faktor-faktor yang dapat mempengaruhi perkembangan prenatal, mulai dari hormone, faktor ibu, ayah, maupun lingkungan. Masa pranatal merupakan masa sangat berpengaruh bagi anak untuk perkembangan ke depannya. Sebagai orangtua, perlu perhatian yang maksimal dari setiap masa yang akan dilewati anak. Perhatian-perhatian ini dimaksudkan agar tidak terjadi berbagai hal yang tidak diinginkan pada sang calon bayi. Banyak faktor yang mengancam kondisi fisik maupun psikis bayi selama di dalam kandungan. Selain itu, tidak hanya orangtua, keluarga dan juga lingkungan juga harus mendukung dalam perkembangan anak di masa pranatal. Orangtua harus memenuhi segala kebutuhan yang menunjang baiknya proses perkembangan ini.

\section{DAFTAR PUSTAKA}

Aprilia, Wahyu. 2020. Perkembangan pada Masa Pranatal dan Kelahiran, Yaa Bunayya: Jurnal Pendidikan Anak Usia Dini.

Desmita. 2005. Psikologi Perkembangan. Bandung: PT Remaja Rosdakarya. 
Nurul Maziyatul H, Dewi Fahmi A, Avita Febri H, Perkembangan Kognitif, Fisik, Dan Emosi Sosial Pada Masa Prenatal

Fatih, Muhamad.2020. Implementasi Profetik Prenatal dan PAUD, Al Hikmah: Indonesian Journal Of Early Childhood Islamic Education.

Hurlock, Elizabeth B .1991. Psikologi Perkembangan Suatu Pendekatan Sepanjang Rentang Kehidupan Edisi Kelima, terjemahan Development Psychology A Live-Span Approach, Fifth Edition oleh Istiwidayanti dan Soedjarwo. Jakarta: Erlangga.

Mansur. 2009. Mendidik Anak Sejak Dalam Kandungan Kado Buat Pengantin Baru, Calon Ibu dan Ibu Hamil. Yogyakarta: Mitra Pustaka.

Marliani, Rosleny. 2015. Psikologi Perkembangan. Bandung: Cv Pustaka Setia.

Pamilu, Anik. 2007. Mendidik Anak Sejak dalam Kandungan (Pandangan Lengkap Cara Mendidik Anak Untuk Orang tua). Yogyakarta: Citra Media.

Pieter, Herri Zan dan Namora Lumongga Lubis. 2016. Pengantar Psikologi untuk Kebidanan Edisi Revisi.Jakarta: Prenadamedia Group.

Riksani, Ria. 2013. Dari Rahim Hingga Besar Mendidik Buah Hati Menuju Ridha Ilahi. Jakarta: Elex Media Komputindo.

Rochmah, Elfi Yuliani. 2005. Psikologi Perkembangan. Yogyakarta: Teras.

Soenarwo, Briliantono M. 2012. 360 Pekan Masa Keemasan Anak; Sekali Seumur Hidup. Jakarta: Halimun Medikal Centre dan Al-Mawardi Prima.

Uhbayati, Nur. 2009. Long Life Education: Pendidikan Anak Sejak Dalam Kandungan Sampai Lansia. Semarang: Walisongo Press. 